\title{
THE QUALITY OF LABOR RESOURCES OF AGRICULTURAL ENTERPRISES OF THE CRIMEA AND THE SOUTHERN REGIONS OF THE UKRAINIAN SSR IN 1945 - THE EARLY 1950s
}

\author{
Pavlo Satskyi \\ PhD, Adjunct Professor, Kyiv National Economic University \\ named after Vadym Hetman, Ukraine \\ e-mail: pavangard@i.ua, orcid.org/0000-0003-3817-7971
}

\section{Summary}

The political decisions of the leadership of Soviet Union and Ukrainian SSR, made after the Second World War, were aimed at ensuring a uniform social and economic development of the European part of the country, taking into account the state of the regional resource base. This approach was also used in making political decisions regarding the Crimea and Ukraine. Therefore, it is necessary to analyze the state of labor resources of the peninsula and surrounding regions of Ukrainian SSR in the initial period of implementation of social and economic development programs concerning them. The purpose of the study is to provide a comparative analysis of the labor resources of the Crimea and the surrounding regions of Ukrainian SSR and the principles and approaches to their use. Therefore, the main study subject is the able-bodied population of the Crimea and the regions of Ukrainian SSR adjacent to the peninsula and its use in the policy of the Soviet leadership. The consideration of the situation and approaches to the use of labor resources in the Crimea region indicates the low efficiency of their use and the lack of opportunities at the regional level to increase it. In the course of the study, it was found that the leadership of the USSR and the RSFSR was not interested in implementing a comprehensive program of improving the efficiency of the labor resources use in the Crimea region due to the lack of grounds for it at the national level.

Keywords: Crimea region, labor resource, collective farms of the Crimea, Kherson region of the UkrSSR, electrification of agriculture, debts of collective farms.

\section{DOI: https://doi.org/10.23856/3876}

\section{Introduction}

After the end of World War II in 1945, the socioeconomic rehabilitation policy was rolled out on the European USSR (Union of Soviet Socialist Republic or Soviet Union) territories affected by warfare, in particular, those of the Ukrainian SSR (Ukrainian Soviet Socialist Republic). Such Soviet power's policy became known as the "national economy rehabilitation policy" both officially and in scientific literature. In the period after the war ended, management of physical, labor, and financial resources was of command-and-control nature and had a vertically integrated structure. Such approach to socioeconomic policy management was premised on the Soviet leadership's political motivation to achieve, in a short period, superiority over Western countries whom they viewed as a potential enemy. In doing so, the USSR sought to achieve a high economic performance relying mainly on its own resource base, and therefore, the need for maximum centralized resource mobilization and distribution became more urgent. Under the appropriate conditions of socioeconomic development policy implementation, approaches to physical and labor resource management at a regional level became of special importance in carrying it out. 
The problems of regional socioeconomic development in the Soviet period was not appropriately covered in scientific literature. The system of social and economic policy management in the USSR after the end of World War II was centralized and did not take into account regional peculiarities. In particular, the problem of labor resource condition in regions, as evidenced by information from working meetings, was often studied superficially with only quantitative data of labor pool considered. Difficulties and poorly predicted, under the command-and-control system conditions, consequences of such approach to labor resource recording and management often caused the need for making political decisions that had socioeconomic consequences in a long-term perspective. As seen from working documents covering the period after World War II, as it involved labor resources in implementation of socioeconomic development programs in the Ukrainian SSR, the Ukrainian government expressly relied on using regional approaches to studying and recording them and identifying prospects of their use.

The subject of research are the labor resources of agricultural enterprises in the mainland Ukrainian SSR in 1947 and Zaporizhzhya and Kherson Oblasts (administrative-territorial unit in the USSR). These regions are located near the Crimean Oblast (a part of the Russian Soviet Federation Socialist Republic until 1954), and the condition of agriculture and labor resources in that sector in Crimean Oblast immediately before its transfer to the Ukrainian SSR in 1954. It should be noted that the condition of agriculture and labor resources in Zaporizzhia and Kherson Oblasts in 1947 was similar to that in the Crimea in 1954. However, the set of measures to provide conditions for agricultural and labor resource development in the mainland Ukrainian oblasts implemented by the Ukrainian SSR government laid the groundwork for their efficient functioning.

\section{Research of problem and historical sources}

The problems of labor resource condition and uses in the southern Ukrainian SSR oblasts and the Crimea was in the focus of attention on the part of both Soviet and contemporary researchers. It should be noted, however, that specialized researches into that problem were only focused on the Crimea, in particular, specific sections in the work of V. Paschenia (Pashchenya, 2008). That researcher's interest in such set of problems was due, obviously, to the fact that he dedicated all his scientific career to regional Crimean history specifically. In his works, however, V. Paschenia attempts to highlight a considerable and unique Crimean potential, also including the postwar period, and possibilities to unlock it autonomously. In particular, that author takes a favorable view of the works dedicated to postwar economic development of the Crimea that stress the feasibility of economic self-reliance for development (Pashchenya, 2013). In most of them, the condition of and approaches to the use of labor resources in the Crimea and southern Ukrainian SSR regions were studied in the context of the Soviet government's policy to cover the entire Soviet Union and the Ukrainian SSR. Noted in particular should be M. Loboda's thesis paper "The Use of Labor Resources in the Ukraine's Heavy Industry Rehabilitation (1943-1950)" (Loboda, 2007). The paper analyses the source of mobilizing the labor resources that were mobilized for heavy industry, and the main focus is made on workers who did not possess full rights, that category included prisoners of war, imprisoned persons, and returnees. The researcher's focus on such categories is due to wide possibilities to mobilize such labor resource unlike collective farm workers. Mild interest to regional development and regional policy on the part the Soviet government on the USSR and Ukrainian SSR level after the end of World War II gave rise to researcher interest to the problem of using the labor resources for the nationwide and republican policy in that sector. 
Yu. Pyliavets's thesis research is dedicated to the problem of collective farm labor resources in the Ukrainian SSR, and the author analyses the ruling party's and Soviet government's policy of developing agricultural enterprises in the Ukrainian SSR in late Stalin's period in it (Pilyavets, 1992). Works of foreign researchers were also dedicated to the problems of socioeconomic policy in the USSR after the end of World War II. However, inaccessibility of archive materials for the authors should be mentioned as their main weakness, and hence, the authors had to use information from open sources that did not fully reflect the state of affairs in the USSR, thus the foreign researchers could not use precise data.

The objective of the study is to analyze the labor resource condition in Ukrainian SSR oblasts agriculture as implementation of the programs aimed at its development and in Crimean Oblast was launched on the eve of including the latter in the Ukrainian SSR in 1954 and the approaches to its development and use by the Soviet government.

The study is based on documents of working correspondence between government authorities and agencies in the Ukrainian SSR and the ruling Communist Party (of Bolsheviks) of Ukraine in the postwar period. Actually, those documents covered all facets of the Soviet period's Ukrainian society which the ruling party attempted to cover by its control in the totalitarian state conditions. Documents containing managerial decisions of Soviet socio-economic policy contain detailed information on specific measures. These measures are obvious to us in the context of the policies of the ruling Communist Party. The policy of the ruling Communist Party was based on the needs of the development of the entire Soviet Union. A study of specific set of problems requires its abstracting from general problems which the government and ruling party authorities attempted to solve under the conditions of totalitarian control over socioeconomic processes. The totalitarian nature of government in the USSR resulted in the ideological conditionality of setting tasks. Therefore, regional approaches were not used in the development of the methodology for managing socio-economic processes. However, abstract tasks to minimize costs, streamline the use of resources, and use local resource base were assigned to regional administrative institutions. The research involves comparative study of numeric data in the working correspondence documents and reports given the specific conditions that prevailed in the period covered by the study. The researchers paid little attention to the state of labor resources in Crimea's agriculture after the Second World War. The comparison of the state of labor resources in the agriculture of Crimea and the adjacent regions of Ukraine was completely neglected.

\section{Comparative analysis of labor resources of the Crimea and the southern regions of the Ukrainian SSR}

In the agricultural in USSR after the end of World War II prevailed the system of collective farms. The means of production funds in agriculture were owned by the collective farms and the peasants were obliged to work at these enterprises. According to the statistics information for the Central Committee of the Communist Party (Bolsheviks) of Ukraine in 1947 in the collective farms of the Zaporozhye region there were 225.9 thousand able-bodied people. Only 58.6 thousand able-bodied workers of collective farms of Zaporizhzhya Oblast were male. It was the result of human casualties during World War II. Out of the total working population in Zaporizhzhya region, 58.6 thousand people were employed in collective farms and MTS [machine-tractor stations]. 36,2 thousand persons were recognized as fit for work in industry in the first quarter of 1947. In Kherson Oblast, there were 146.9 thousand persons of employable population, of which 39.7 thousand of male population, employed at collective farms and MTSs 
were 41.8 thousand persons, and 25.1 thousand persons were identified as usable in industry throughout Kherson Oblast. In 1947, there were 1,230 collective farms and 1,722 households in the Zaporizhzhia region, and 898 collective farms and 1,127 households in the Kherson region (Spravka o nalichii, 1947: 138). Hence, it should be noted that, in contract to the state of affairs in Crimean Oblast as at 1951, the situation at collective farms in the adjacent Zaporizzhia and Kherson Oblasts was slightly better, as the numbers of employable population and workforce reserve were considerably larger, and there were some little more employable persons per one household. In addition, the specificity of postwar demographic situation, featuring evident percentage of male population out of total employable persons, should be considered. A tendency towards a more rapid agricultural was noticed in more industrially developed Zaporizzhia Oblast as compared with problem Kherson Oblast.

According to the Crimean Oblast Statistical Department, as at January 1, 1954, a total of 973,466 persons resided in the oblast, of those, 581,896 persons lived in cities, and 391,570 persons lived in villages. According to the same information letter, 219,329 persons of working age lived in villages (Svedeniya o chislennosti, 1954: 50). Such data were derived by the Crimean Oblast Statistical Department analytically and they were approximate, in particular the data regarding the rural and urban population. Additionally, those data did not include the number of militaries and other groups of population in the Crimea (such groups are not specifically detailed in the report) (Nachalnik Statupravleniya Krymskoy oblasti, 1954: 49). While such data are approximate and not recommended for use as official, they enable to assess the demographic condition in Crimean Oblast in the year of its transfer to the Ukrainian SSR. Hence, the number of rural population in the Crimea was some 40 percent, and the share of working age was approximately 25 percent. And the share of rural population was some 59.8 percent. Considering the undeveloped Crimean Oblast's industry, Crimean cities experienced a material demographic burden. To study the demographic situation in the collective farms of the Crimea, it is necessary to analyze the data of the collective farms of the southern regions and the steppe zone. In particular, the population in Alushta District totaled 18,095 persons, of those, urban population was 7,918 persons and rural population, 10,177 persons, and of those, employable population was 5,988 persons; and in Sudak District, 11,294, 2,534, 8,760, and 4,996 persons respectively. As per those districts, notable is the ratio between the overall population and the urban, rural, and employable rural population: in Alushta District, the share of urban population was some 43.7 percent, rural population, over 56 percent, and of those, employable population, approximately 33 percent. In Sudak District, the respective percentage was: 22.4 percent, some 77.6 percent, and approximately 44.2 percent. Hence, it should be noted with respect to those Crimean districts, that rural population prevailed over urban, regardless of the developed recreation sector in cities of those districts. In villages of those districts, collective farms specialized in cultivating grape, tobacco, meat and milk, and wool (Vypolneniye obyazatelstv pered gosudarstvom v 1951 g. kolkhozami Yaltinskogo, 1951: 43).

For comparison, the Crimean steppe districts should be considered. In particular, in Prymorsky District, the population totaled 20,654 persons, of those, urban population was 970 and rural was 19,684 persons, and of those 11,146 persons were employable. That is, in percentage terms, urban population was some 4.7 percent, rural was over 95 percent, and of those employable was approximately 54 percent. As regards one more district, Chornomorsky, its population totaled 11,142 persons, there was no urban population, and employable were 6,399 persons, that is, slightly more than 57 percent. Similar situation was in Leninsky District where the population totaled 14,701 persons, there was no urban population, and 8,290 persons of rural population, or slightly over 56 percent, were employable. Collective farms in those districts 
mainly focused on grain growing and, apart from grain crops, sunflower, vegetables, meat, milk, wool, and eggs (Vypolneniye obyazatelstv pered gosudarstvom v $1951 \mathrm{~g}$. (kolkhozami Krimskoy oblasti), 1951: 26).

For reference, interesting the situation with the number of households and population at collective farms in Alushta and Sudak Districts where, according to the information letter as at 1951 , recorded households totaled 2,362 in those two districts, the population in the same households of the two districts was 8,142 persons, and 4,013 of them were employable (Svedeniya o nalichii dvorov $i$ naseleniya $v$ kolkhozakh Yaltinskogo, 1951: 47). The working population in the collective farms of Sudak and Yalta districts of Crimea was less than half of all collective farm workers. In the collective farms of the Primorsky, Lenin and Black Sea regions, the total number of households was 992 . The population of these households was 3154 people. Of the 3,154 people in the collective farms of the Primorsky, Lenin and Black Sea regions, 1522 people were able to work (Svedeniya o nalichii dvorov i naseleniya (u kolgospakh Evpatoriyskogo...), 1951: 22-23). Also, the share of employable population in those grain-growing districts was slightly smaller than one half of the total number. At the same time, as at 1951, the total debt of collective farms in those districts was, according to the information letter, 7,279.2 thousand rubles (including 1,179.6 thousand rubles, or 16.2 percent, to collective farmers) (Zadolzhennost kolkhozov (Evpatoriyskogo ...), 1951: 32). For comparison, at collective farms in Alushta and Sudak Districts, farms' debt was 6,699.8 thousand rubles (including 2,169 thousand rubles, or 32.4 percent, to collective farmers) (Zadolzhennost kolkhozov Yaltinskogo ...), 1951: 53). That is, at farms focused on grain, the debt was 7,279.2 thousand rubles per 992 households and 3,154 persons, and at collective farms specialized in specialty crops, 6,699.8 thousand rubles per 2,362 households and 8,142 residents. Therefore, noteworthy is the tendency that the percent of debt to collective farmers at collective farms specializing in grain was almost twice lower than at collective farms focusing on specialty crops. At the same time, the overall debt is indicative of higher workload per one collective farmer exactly at collective farms with grain focus: 2.3 thousand rubles per one collective farmer or almost 4.8 thousand rubles per one employable person. Conversely, the debt situation at collective farms focusing on specialty crops was different, and the amount was some 0.8 thousand rubles or almost 1.7 thousand rubles per one employable person. Therefore, an advantageous difference in the socioeconomic condition of collective farms focusing on specialty crops in the Crimea should be stated. Such tendency resulted from more profitable conditions that were provided by Soviet authorities for grape growing collective farms and was due to more favorable conditions of managing a farm focusing exactly on specialty crops.

The unfavorable farm management conditions in the steppe Crimea was noted even when the construction of the South Ukrainian and North Crimean Canals began, particularly noted was the fact that the Crimea needed water supply even more than the southern districts of Ukraine (Stenogrammy dokladov, 1950: 38). To support the Crimean economic development after the war ended, a program to facilitate cultivation of specialty agricultural crops, especially viticulture, was envisaged.

Socio-economic development in the Ukrainian SSR took place through the implementation of projects. The projects were implemented under the direct control of the Communist Party of Ukraine organizations by the executive authorities. Such management could only be efficient owing to sufficiency of local natural resources and workforce or resources coming within centralized nationwide distribution. Mainly in-house resources for projects that were of interest for specific agencies could be sourced for the Crimea. The Crimean agriculture was only of interest for the Ministry of Agriculture to the extent of cultivating the specific industrial 
crops: viticulture and tobacco cultivation. That was owing to unique nature of those sectors in the first turn as well as to administrative incentives and instant return. In particular, incentives for Crimean vine growers were much higher than in the Ukrainian SSR. Specifically, in their letter to J. Stalin of August 30, 1947, Chairman of the Ukrainian SSR Council of Ministers M. Khrushchev and First CC KP(b)U Secretary L. Kahanovych requested that the same conditions of contracting hybrid grape varieties as in the Crimea be provided for collective farms and collective farmers in Zakarpattia [Trans Carpathian] Oblast. Such conditions for the Crimea were set by Resolution of the USSR Council of Ministers, dated July 7, 1947 whereby, for each ton of grape supplied on the contracting terms, 1.8 hundred kilograms of grain would be delivered on counter-sale basis to the suppliers. Hence, the Soviet government attempted to use any opportunities for promoting the economic activities of collective farms and collective farmers in the Crimea. In that context, maximum use of local resources and facilities was preferred. In this instance, the endeavor to use such local resource as climatic conditions, enabling to raise local-level crops, should be noted.

Noteworthy for late Stalin's period are the Soviet government's attempts to maximize the exploitation of natural resources, in particular, also in agriculture, for cultivating most efficient and economically sound crops. It was such features of the Soviet agricultural policy that the attempts to cultivate in the UkrSSR cotton plant and other crops, which were of low output for those latitudes, could be explained. Different crops, including those conditions for cultivating which were scarcely favorable, such as grain crops, were also cultivated in the Crimea until transferred to the UkrSSR. Their yield at collective farms with grain specialization, as shown by the Crimean Oblast Statistical Department's data, was moderate. However, their cultivation enabled to ensure the employment of collective farm population and operation of the Crimean economy, which was politically motivated under the conditions after deportation of the indigenous peoples from the peninsula in 1944. In particular, the grain crop yield in 1951 was 9.6 hundred kilograms per hectare in the coastal Crimea, 17.1 hundred kilograms per hectare on average at Chornomorsky District collective farms, and 12.75 hundred kilograms per hectare on average in Leninsky District.

The collective farms of the Crimea growing unique crops had significantly less able-bodied population than the collective farms growing the grain. In the collective farms in the territory of the Crimea peninsula, there was a small working population. In the southern regions of the Ukrainian SSR, the situation with the working-age population was better. Therefore, in the Ukrainian SSR, the able-bodied population of collective farms was involved in work in industry and transport.

The program of rehabilitating residential, industrial and public amenity facilities was launched in the Ukrainian SSR even before the war ended. The rural electrification program was actively implemented in 1947. Provision of electricity to 153 collective farms, 5 state farms, and enterprises that provided services to agricultural industry in Zakarpattia Oblast was planned for that year. For that purpose, construction of 30 rural electric power plants of $650 \mathrm{~kW}$ in total power, 115 high-voltage substations and transformer vaults, and $727 \mathrm{~km}$ of transmission lines was envisaged. An important role in the implementation of this program in Zaporizzhia Oblast was assigned to 49 industrial enterprises who were to give voluntary assistance to collective farms for their electrification (Sekretaryu TsK KP(b)U Kaganovichu L. M, 1947: 187-188). Therefore, notable is the traditional Soviet approach to providing agricultural development conditions that consisted in placement of obligations to provide such development conditions upon efficient enterprises. Accordingly, possibilities to upgrade agricultural enterprises emerged if local resources, developed by enterprises with different profiles, could be used. 
Alongside with enhancement of capacities in agricultural production, activity to provide conditions for populating prospective agrarian regions was undertaken in the Ukrainian SSR. For that purpose, the republic-wide agricultural construction program was implemented. As at 1946, there were 691 construction teams with 6,079 workers in them in Zaporizzhia Oblast and 390 teams with 3,570 persons in them in Kherson Oblast (Kolichestvo stroitelnykh brigad, 1946: 52). The pace of agricultural facility construction was found unsatisfactory and the construction plan failed at the Kherson Oblast KP(b)U Committee Bureau meeting on January 13,1948 . As was stated, only 2,840 out of planned 3,526 facilities, of those 1,546 houses, were built, which accounted to only 67 percent of the plan, and 1,094 industrial facilities were built, which was 120 percent of the plan (Vytiah iz protokolu № 184, 1948: 1).

In Zaporizzhia Oblast, the situation with construction at collective farms was much better than in Kherson Oblast. As at August 1948, as many as 1,168 teams with 11,671 workers were organized, and 24,994 houses out of 36,042 destroyed during the war were built, and 6,546 industrial facilities out of 8,951 destroyed were renovated in three postwar years. It should also be noted that resolution of Zaporizzhia Oblast Executive Committee and Oblast KP(b)U Committee Bureau stressed the special importance of supplying local construction materials for that program; in particular, 120 brick, 10 tile, and 10 lime kilns were built [Постановление исполкома Запорожского, 1948, Арк. 244]. Similarly, in Kherson Oblast, attention was paid to development of the industry that produced construction materials locally. The minutes of the meeting of the Bureau of the Committee of the Communist Party (Bolsheviks) of Ukraine of Kherson region of January 23, 1948 recorded the implementation of the plan of production of building materials. The overall plan for the production of building materials for 1947 was fulfilled by 100.9 percent overall in the region. The production plan for specific types of building materials has not been implemented (Vytiah z protokolu biuro Khersonskoho, 1947: 7).

The results of analysis confirm the general tendency of inconsistency of the USSR's official data about the growth in collective farm production volumes with actual state of affairs at not only nationwide scale, as was mentioned in Yu. Pyliavets's work (Pilyavets, 1992), but regionally as well, as illustrated with the presented statistical data. It should be noted, however, that the best prospects for efficient use of labor resources existed in those regions, whose socioeconomic development was among Soviet government's priority, which fact researches M. Loboda and O. Titika point out in their works (Titika, 2015). The analysis of the state of the Crimean labor resources after the Second World War gives a complete understanding of the situation by comparing their situation and approaches to use with the Zaporizhzhya and Kherson regions of the Ukrainian SSR. The government of the Ukrainian SSR and the Communist Party of Ukraine carried out the policy of development of Zaporizhzhya and Kherson regions.

\section{Conclusions}

The official Soviet position both in the period, the conditions and measures of economic use of labor resources in which are analyzed in the study, and in later periods demonstrated constant improvement of qualitative and quantitative indicators of labor resources in all Ukrainian SSR regions and adjacent oblasts of other republics. However, the data presented in the research testify to domination of the resource mobilization methods for implementing specific politically motivated projects in their use. It was such approach in the post-World War II period that conditioned a considerable Soviet government's attention to socioeconomic development of the Ukrainian SSR oblasts that were adjacent to the Russian Soviet Federation Socialist Republic Crimean Oblast by providing acceptable conditions for placement of 
labor resources and manufacturing facilities in agrarian regions of Ukraine's southern oblasts. Implemented were programs of constructing houses for workers of agricultural enterprises and their electrification policy, which was nationwide and covered the entire USSR. The situation with labor resource at agricultural enterprises in Crimean Oblast proved to me more complicated. Only enterprises that cultivated specialized crops such as grape, tobacco, etc. had possibilities for normal operation. Those collective farms had much smaller population than those mainly focused on growing grain crops. The state supported the collective farms by growing grapes, burying the products of these collective farms at prices higher than the products of collective farms that grew grain. He pursued such a policy in the Crimea and the USSR. Therefore, more stringent operation conditions were set for collective farms in the southern Ukrainian SSR oblasts in the period after World War II, and at the same time, the policy of their social and industrial development was implemented. As regards collective farms in Crimean Oblast, the policy was limited to only provision of more favorable economy management conditions for collective farms focusing on specialized crops. As the Soviet policy of maximum labor resource use at agricultural enterprises in the southern Ukrainian SSR oblasts, in particular, also for their socioeconomic development, produced considerable positive results with maximum use of local resources, it promoted implementation of larger-scale regional development programs such as construction of electric power plants, transmission lines, and irrigation systems. In that way, foundation for development of regions with specific economic management conditions and their assimilation and bringing employable population to them by using specific regional resource base was laid. Crimean economic development programs have shown greater effectiveness in the implementation of these programs by the government of the Ukrainian SSR and the ruling Communist Party of Ukraine in the republic. Therefore, the government of the USSR in 1954 decided to include the Crimean region in the Ukrainian SSR.

\section{References}

Vypolneniye obyazatelstv pered gosudarstvom v $1951 \mathrm{~g}$. (kolkhozami Krimskoy oblasti) [Fulfilment of obligations to the state in 1951 (collective farms of the Crimea Oblast)] // TsDAGO Ukrainy (Central State Archives of Public Organizations of Ukraine, Kyiv), f. 1, op. 24, spr. 3843 [in Russian].

Vypolneniye obyazatelstv pered gosudarstvom v 1951 g. kolkhozami Yaltinskogo, Alushtinskogo, Sudakskogo rayonov [Fulfillment of obligations to the state by the collective farms of Yalta, Alushta, Sudak districts in 1951] // TsDAGO Ukrainy, f. 1, op. 24, spr. 3843 [in Russian]. Vytiah iz protokolu № 184 p. 23 zasidannia Biuro Khersonskoho obkomu KP(b)U 13 sichnia $1948 \mathrm{~g}$. "O plane selskoho y kolkhoznoho stroytelstva v oblasty na 1948 god" [Excerpt from Minutes No. 184, Item 23 of the Meeting of the Bureau of the Kherson Regional Committee of the Communist Party (Bolshevik's) of Ukraine and "On the Plan of Rural and collective farm construction in the region for 1948” (January 13, 1948)] // TsDAHO Ukrainy, f. 1, op. 23, spr. 5149 [in Ukrainian].

Vytiah z protokolu biuro Khersonskoho obkomu KP(b)U 23 sichnia 1948 g. "Ob ytohakh rabotbl predpryiatyi oblasty, proyzvodiashchykh stroimateryaly za 1947 god v plane proyzvodstva na 1948 god" [Excerpt from the minutes of the bureau of the Kherson Regional Committee of the Communist Party (Bolshevik's) of Ukraine "On the results of work of enterprises of the region, producing building materials for 1947 and the plan of production for 1948" (January 23, 1948)] // TsDAHO Ukrainy, f. 1, op. 23, spr. 5149 [in Ukrainian]. 
Zadolzhennost kolkhozov (Evpatoriyskogo, Pervomayskogo, Kirovskogo, Primorskogo, Rozdolnenskogo, Chornomorskogo, Leninskogo, Dzhankoyskogo i Bakhchisarayskogo rayoniv na 1951) [Debt of collective farms (Evpatoriysky, Pervomaisky, Kirovsky, Primorsky, Rozdolnensky, Chornomorsky, Leninsky, Dzhankoysky and Bakhchisaraysky districts in 1951)] // TsDAGO Ukrainy, f. 1, op. 24, spr. 3843 [in Russian].

Zadolzhennost kolkhozov Yaltinskogo, Alushtinskogo i Sudakskogo rayonov (na 1951 g.) [The debt of the collective farms of Yalta, Alushta and Sudak regions (1951)] // TsDAGO Ukrainy, f. 1, op. 24, spr. 3843 [in Russian].

Loboda, M. (2007). Vykorystannia trudovykh resursiv u vidbudovi vazhkoi promyslovosti Ukrainy (1943-1950 rr.): avtoref. dys. ... k-ta ist. nauk: 07.00.01. [The use of manpower in the reconstruction of the heavy industry of Ukraine (1943-1950) PhD diss.] Kyiv: In-tut Istorii Ukrainy NAN Ukrainy [in Ukrainian].

Kolichestvo stroitelnykh brigad $i v$ nikh rabotayushchikh kolkhoznikov po oblastyam USSR $v$ 1946 godu [The number of construction crews and collective farmers working in them in the regions of the Ukrainian SSR in 1946] // TsDAGO Ukrainy, f. 1, op. 23, spr. 4718 [in Russian]. Nachalnik Statupravleniya Krymskoy oblasti N. Tochenyy brigade TsK KP Ukrainy. 15 marta $1954 \mathrm{~g}$. [Information of the Head of the Statistical Office of the Crimean Region N. Tocheny for the Central Committee of the Communist Party of Ukraine (March 15, 1954)] // TsDAGO Ukrainy, f. 1, op. 24, spr. 3862 [in Russian].

Pashchenya, V. (2013). Istoriografiya krymovedeniya: monografiya [Historiography of Crimean Studies: monograph]. Simferopol: DIAYPI [in Russian].

Pashchenya, V. (2008). Krymskaya oblast v sovetskiy period (1946-1991 gg.): Monografiya [Crimean region in the Soviet period (1946-1991): Monograph]. Simferopol: DIAYPI [in Russian] Pilyavets, Yu. (1992). Kolkhozy Ukrainy v vosstanovitelnyy period: problemy $i$ trudnosti (1943-1950 gg.) : avtoref. dis... k-ta ist. nauk: 07.00.02 [Ukrainian collective farms in the period of reconstruction: problems and difficulties (1943-1950) PhD diss.]. Kyiv: In-tut Istorii Ukrainy NAN Ukrainy [in Ukrainian].

Postanovleniye ispolkoma Zaporozhskogo oblastnogo Soveta deputatov trudyashchikhsya $i$ byuro obkoma KP(b)U № 51/8 ot 7 avgusta 1948 g. O vypolnenii postanovleniya SNK USSR $i$ TsK KP(b)U ot 27 aprelya 1945 goda o stroitelstve zhilykh domov kolkhoznikov. proizvodstvennykh postroyek $v$ kolkhozakh i kulturno-bytovykh zdaniy na sele [Resolution of the Executive Committee of the Zaporizhzhya Regional Council of Workers' Deputies and the Bureau of the Communist Party (Bolshevik) District Committee No. 51/8. On the implementation of the decision of the Council of People's Commissars of the Ukrainian SSR and the Central Committee of the Comunast Party (Bolshevik's) of Ukraine of April 27, 1945 on the construction of residential buildings for collective farmers, industrial buildings on collective farms and cultural and residential buildings in the village (August 7, 1948)] // TsDAGO Ukrainy, f. 1, op. 23, spr. 5149 [in Russian].

Svedeniya o chislennosti naseleniya Krymskoy oblasti na 1 yanvarya 1954 goda [Information on the population of the Crimean region on January 1, 1954] // TsDAGO Ukrainy, f. 1, op. 24, spr. 3862 [in Russian].

Svedeniya o nalichii dvorov i naseleniya (u kolgospakh Evpatoriyskogo, Pervomayskogo, Kirovskogo, Primorskogo, Rozdolnenskogo, Chornomorskogo, Leninskogo, Dzhankoyskogo $i$ Bakhchisarayskogo rayoniv na 1951 r.) [Information about the presence of households and the population (at the collective farms of the Evpatoriya, Pervomaisky, Kirovsky, Primorsky, Rozdolnensky, Chornomorsky, Leninsky, Dzhankoysky and Bakhchisaraysky districts in 1951)] // TsDAGO Ukrainy, f. 1, op. 24, spr. 3843 [in Russian]. 
Svedeniya o nalichii dvorov i naseleniya v kolkhozakh Yaltinskogo, Alushtinskogo i Sudakskogo rayonov (na 1951) [Information on the availability of households and population on collective farms of the Yalta, Alushta and Sudak districts (in 1951)] // TsDAGO Ukrainy, f. 1, op. 24, spr. 3843 [in Russian].

Sekretaryu TsK KP(b)U Kaganovichu L. M. "Dokladnaya zapiska o khode elektrifikatsii selskogo khozyaystva Zaporozhskoy oblastiv 1947 godu” (vid) Sekretarya obkoma KP(b)U L. Brezhneva. 20 noyabrya $1947 \mathrm{~g}$. [The Secretary of the Zaporizzij Regional Committee of the Communist Party (Bolshevik's) of Ukraine L. Brezhnev to the Secretary of the Central Committee of the Communist Party (Bolshevik's) of Ukraine Kaganovich L. M. "Report on the progress of electrification of agriculture in Zaporizhzhya region in 1947” (November 20, 1947)] // TsDAGO Ukrainy, f. 1, op. 23, spr. 4583 [in Russian].

Spravka o nalichii trudosposobnykh v kolkhozakh UkrSSR i kolichestve kolkhoznikov, kotoryye mogut byt ispolzovany na period 1-go kvartala $1947 \mathrm{~g}$. v promyshlennosti [Information on the availability of able-bodied people on the collective farms of the Ukrainian SSR and the number of collective farmers who can be used in the period of the 1st quarter of 1947 in industry] // Tsentralniy derzhavniy arkhiv gromadskikh ob'ednan Ukrainy, f. 1, op. 23, spr. 4051 [in Russian].

Stenogrammy dokladov nachalnika "Ukrvodstroya” tov. Bochkina A. E. i nachalnika "Dneprostroya” tov. Andrianova S. N. o stroitelstve Kakhovskoy gidroelektrostantsii. Yuzhno-Ukrainskogo i Severo-Krymskogo kanalov. $1950 \mathrm{~g}$. [Transcripts of reports by the head of "Ukrvodstroy" Comrade A. Bochkin and the head of "Dneprostroy" Comrade Andrianov S. N. for the construction of the Kakhovka hydroelectric power station, the South-Ukrainian and NorthCrimean canals. 1950] // TsDAGO Ukrainy, f. 1, op. 24, spr. 236 [in Russian].

Titika, O. (2015). Vidbudova i funktsionuvannia mistsevoi promyslovosti Ukrainy v 1943-1950 rr. Monohrafiia [Rebuilding and functioning of local industry of Ukraine in 1943-1950. Monograph]. Cherkasy: "Vertykal", vydavets Kandych S. H. [in Ukrainian]. 